\title{
The Concept of Society in the Making of the Nordic Welfare State
}

\section{Kettunen, Pauli}

Edward Elgar

2019

Kettunen , P 2019 , The Concept of Society in the Making of the Nordic Welfare State . in S

Kuhnle , P Selle \& S E O Hort (eds), Globalizing Welfare: An Evolving Asian-European

Dialogue ., 9 , Globalization and Welfare series , Edward Elgar , pp. 143-161 . https://doi.org/10.4337/97817889758

http://hdl.handle.net/10138/313699

https://doi.org/10.4337/9781788975841.00018

acceptedVersion

Downloaded from Helda, University of Helsinki institutional repository.

This is an electronic reprint of the original article.

This reprint may differ from the original in pagination and typographic detail.

Please cite the original version. 
Final manuscript of Chapter 9 in: Stein Kuhnle, Per Selle \& Sven E. O. Hort (eds) Globalizing Welfare: An Evoking Asian-European Dialogue. Edward Elgar Publishing, Cheltenham 2019, pp. 143-161.

DOI: $\underline{10.4337 / 9781788975841.00018}$

Pauli Kettunen

\section{The concept of society in the making of the Nordic welfare state}

"The Great Society" was what Lyndon B. Johnson named his programme aimed at extending the social responsibilities of government. At the same time, Tage Erlander urged the Swedish Social Democrats to build a "Strong Society". Later, Margaret Thatcher declared that "there is no such thing as society". However, this did not hinder her successor, David Cameron, from his ambition of creating "the Big Society" by shrinking the social responsibilities of government.

"Concepts are more important for what they do than for what they mean", as Nikolas Rose $(1999,9)$ puts it. The concept of society has served a great number of needs in linguistic political arsenals. Most obviously, it has played a role in contestations regarding the welfare state. It has been a tool for shaping or shaking up "the normative foundations of the welfare state", to use the phrase Stein Kuhnle and Nanna Kildal employ in their book on the Nordic welfare state model (Kildal \& Kuhnle 2005).

Modern political concepts were constructed in relation to the idea of history as movement, called development or progress. They became, according to Reinhart Koselleck (1979, 344), “instruments for the direction of historical movement". In present national narratives of the Nordic countries, as well as in narratives of Nordicness, the making of the welfare state appears as a great phase of "the historical movement". It is true that social-policy reforms extending the regulative and redistributive functions of the state were associated with views of history as development and progress. However, as recent studies on social-policy language indicate (Béland \& Petersen eds. 2014; Edling ed. 2019), it was only rather late in the twentieth century that the concept of the welfare state played any significant part in efforts to steer this historical movement.

I will argue that in the Nordic countries, "society" was allocated specific meanings that caused it to play a special role in the process that was retrospectively conceptualised as the building of the welfare state. The concept of society has seemingly been associated with an assumption that society does 
something, that is, that it is an agent with its own will and subjectivity, capable of being not just "great" or "big” but also "strong" (Andersson 2006).

I am painfully aware of the problems and risks of generalisations when claiming that a particular concept is characteristic of all Nordic countries. My primary evidence, presented in a few of my earlier papers (Kettunen 2000; 2003; 2014; 2018), is mostly based on how society has been conceptualised in Finland, which I have examined as a particular Nordic case. In this tentative paper, the focus is on specific common Nordic features in the understanding and use of the concept of society. I try to resist the temptation to construct an exotic or nostalgic image of Norden. There are important similarities with societies outside the Nordic region, in particular with the other small European countries to which terms like "democratic corporatism" (Katzenstein 1985) can be applied. Further, as especially the case of Finland implicates, a comparative historical study would benefit from also including those Eastern European agrarian societies that were politically shaped through the collapse or modification of the European empires during and after the First World War.

More generally, it is reasonable to recognise that "society" as an actor is not a unique Nordic phenomenon. The field of sociology credits modern society with having the capacity to set norms, assign roles and teach values. In less theoretical discourses, statements in which society expects, requires or condemns something are familiar outside of Norden as well (Bowers \& Iwi 1993). "Society" in Nordic political discourses bears those particular characteristics that have been part of debates on postmodernity and globalisation, often discussed as the unsustainable modern idea of society (Featherstone 1995; Touraine 1995): it has been fixed to the nation-state, it has referred to an integrated entity with its own subjectivity and it has included progress as its inherent code. However, there is something particular in how these characteristics and, with them, agency has been included in the concept of society in the Nordic countries.

I first discuss the relationship between the concepts of society and state, notably the way Nordic political languages have tended to confuse these two concepts. I will argue that the notion of the state as a society preceded the formation of the welfare state and played a crucial role in providing legitimacy for state interventions in social relations.

The next step of my argument leads to a discussion of the spatiality and temporality of "society". How were the notions of transnational interdependence and historical development associated with the concept of society? Focusing on what can be called the comparative and historical reflexivity of politics, I examine the mode of thought and action in which different national societies were located 
at different places and stages of modernisation, and its implications for defining social problems and solutions.

The adoption of a peripheral perspective towards what were found as centres of modernisation seemed to make society capable of anticipating its own future. The dualism of society as a normative and a descriptive concept, in turn, provided it with the capacity of self-critique: society could be criticised in the name of society by means of the normative standards of society itself. The normative standards were associated with the idea of history as progress, and they implied views on social cohesion, economic rationality and political agency. I argue that the intertwined notions of the anticipatory and self-critical capacities of society were, since the 1930s and, especially, after the Second World War, realised as confidence in a virtuous circle between social equality, economic growth and broadening democracy. This view provided a widely shared, yet contested, framework for the reforms that retrospectively appear as the making of the welfare state.

In this process, the use of "society" as a term for the state, or the public sector, was repeated and reinforced in a way that has made it difficult to operate by contrasting "state" and "society", or "welfare state" and "welfare society", as I conclude in the final part of this paper. Nevertheless, such attempts emerged in the 1980s as part of the right-wing critique of the welfare state, and it has motivated me to begin the analysis with a brief discussion of them.

\section{The state as society}

In Swedish disputes about the welfare state in the 1980s, conceptual historical evidence was utilised and the concept of society was placed in the centre. Right-wing critics argued against what they found as a patronising welfare state, observing that in the Swedish political language no clear distinction existed between "state" (stat) and "society" (samhälle). Not infrequently, "society" appeared where one might expect to see the terms "state" or "public power". Critics concluded that this unique, or so they assumed, conceptual confusion indicated a weakness of liberalism and a kind of social democratic totalitarianism. To overcome these defects, "civil society" (civilt samhälle) had to be created or revitalised (for more on this debate, see Trägårdh ed. 1995).

There is little doubt that Swedes do tend to conflate "state" with "society". They may demand that "society" - rather than private or voluntary actors - take responsibility for social services or, conversely, that "society" should now leave many of its traditional functions to private and voluntary 
actors. However, this kind of conceptual use is not uniquely Swedish. In fact, all Nordic political languages commonly conflate "state" and "society", though differences of degree may be seen in how frequently "society" refers to the state or to the state and municipalities together (Knudsen \& Rothstein 1994).

Perhaps "society" may even in non-Nordic contexts sometimes refer to public authorities or, at least, to public funds and taxpayers as their creators. Nevertheless, it would not be difficult to find examples of such an understanding of society as public authorities, namely samhälle (Swedish), samfund (Danish), samfunn (Norwegian), samfélag (Icelandic) or yhteiskunta (Finnish), in which society, société or Gesellschaft could not serve as translations. The Finnish language is totally different from the Scandinavian languages, but even still this usage of the concept of society is shared by both the Finnish-speaking majority and the Swedish-speaking minority. ${ }^{1}$

The Swedish critics of the social democratic state were wrong when they associated this conceptual historical phenomenon with a strong social democracy. There is much in common in the Swedish and Finnish ways of using this concept, yet in Finland, since the Civil War of 1918, social democracy has been much weaker than in Sweden. In fact, the conceptual confusion regretted by the critics had begun much earlier than the era of the welfare state, an expanded public sector and corporatism, i.e. those practices that the critics referred to as comprising the major links between state and society and the reasons for the lost understanding of the boundaries between them. How should we then understand this conceptual confusion and its political implications?

The thesis on "statist individualism", developed by Lars Trägårdh, deserves attention here. Trägårdh (1995; 1997; Berggren \& Trägårdh 2006) argues that in Sweden and other Nordic countries, the notion of a (civil) society confronting the state never developed because, on the basis of the egalitarian tradition of independent peasants, the liberation of the individual was not directed against excessive state power but against the privileges and patriarchal powers of those between the state and the people. Another factor preventing the conceptual separation of state and society was the absence of conflicts between the state and church and between confessional communities. The Reformation of the sixteenth and seventeenth centuries had set in motion the making of the centralised state, inseparably intertwined with the Lutheran Church and its message of conformity, while Lutheran Christianity at the same time stressed an immediate individual relationship to God.

\footnotetext{
${ }^{1}$ Finnish and Swedish have an equal constitutional status as the two official languages of Finland.
} 
All this resulted, according to Trägårdh, in a social democratic welfare state characterised by "statist individualism". The strong state came to be oriented to securing individual autonomy and individual resources. Social solidarity was realised through high taxes, public systems of social security and vast public services for health, care and education that helped to liberate people from personal

relations of subordination, especially those in the family; as part of the efforts to achieve full employment, women became doubly dependent on the welfare state, both on public-sector jobs and the services that facilitated combining motherhood and employment outside the home. Social security is based on "the individual-state social contract” (Trägårdh 1997, 270).

The thesis on statist individualism did not agree with the critique of the patronising state, but it did agree with the claim regarding the weakness of an autonomous civil society. ${ }^{2}$ Somewhat surprisingly, this thesis has recently gained popularity among right-wing groups, who now, very differently from their arguments in the 1980s, oppose the views of the welfare state as a social democratic achievement and wish to show their own contribution to "the Nordic model". The idea that the promotion of individualism constituted the true essence of welfare-state history seems to be useful not only for fighting against the social democratic claims to ownership of the welfare state, but also for arguing that the politics advocating more individual choice is compatible with the principles of the welfare state (World Economic Forum 2011).

In the form Trägårdh originally presented it, the thesis on statist individualism importantly points out prerequisites for the legitimacy of the state. Yet, curiously it takes the popularity of the concept of society as evidence for the weakness of society. Thus, it fails to give any hint as to why various "sub-state" activities were put into the centre of the concept of "Nordic democracy" as it emerged in the 1930s (Kurunmäki \& Strang ed. 2011). The oldest reference to Nordic democracy can be found in the idealised figure of the free Nordic peasant and the heritage of local, rural self-government. This ideological element of "Nordic democracy" was developed in the $19^{\text {th }}$ century, partly as a result of increasing numbers of popular movements, which themselves were later in the $20^{\text {th }}$ century referred to as yet another aspect of Nordic democracy. Still, a third "sub-state" element appeared at this point. The regulation of employment relations through parity-based negotiations and agreements between voluntary organisations of workers and employers was, since the 1930s, included in the concept of

\footnotetext{
${ }^{2}$ True, there are attempts to combine the thesis of statist individualism and an account of a strong civil society as a Nordic characteristic, most recently in Enjolras \& Strømsnes 2018.
} 
Nordic democracy, especially in how the concept was used in the Nordic cooperation between social democratic parties and trade unions.

The Nordic political languages have seemingly conserved elements from the political philosophy existing before the $19^{\text {th }}$ century when societas civilis did not mean a sphere separate from the state, but was a way of conceptualising the state (Riedel 1975; Bobbio 1989; Heilbron 1995). Arguably, the Nordic use of "society" for the state implied that the state or public power was supposed to be capable of involving the associative, integrative and inclusive principles of "society" and "the

social". Thus, "society" as a term for the state, or for the whole of central and local government, provided the state with an inherent ethical power.

The state or public authorities are not in all situations called society, for example usually not in legal texts. The criteria for situations in which the term "society" could, and still can, be applied to the state and municipalities seem to stem from the notion of society as a moral order of the relationships between individuals or groups. "Society" is applied to public authorities in situations where the relationships between public authorities and individuals or between public authorities and private actors, often those in the sphere called "economy", are looked at from this kind of moral point of view.

In his distinction between the state (Staat) and civil society (bürgerliche Gesellschaft), Hegel associated the state with freedom and the highest form of Sittlichkeit, whereas civil society was the sphere of necessities, especially economies. However, bürgerliche Gesellschaft also included the governmental institutions fulfilling such necessities, for example the wide array of practices that in his time were collectively referred to as the police. In Nordic political languages, Hegel has been turned upside down, although in a sense different from how Marx wished to make this turn. To the extent that the state is looked at from the point of view of its supposedly ethical essence, it is called "society", and the term "state" is more frequently used to describe the formal practices of governmental institutions.

It is tempting to link the societalised state with the specificities of the Enlightenment in the Nordic countries. Bo Stråth and Øystein Sørensen (1997, 3) argue that the Nordic Enlightenment "ironically and paradoxically enough had the peasant as its foremost symbol". The Nordic peasant was a figure of non-utopian pragmatic rationality, a figure that stamped its particular label on the Nordic Enlightenment and Nordic Romanticism as well as on Nordic democracy and the Nordic welfare state. Developing this line of interpretation, Peter Aronsson $(1995 ; 1997)$ suggests that the development of 
the Swedish term samhälle (society) to refer to the state derives from the tradition of local selfgovernment among the free-holding farmers.

One should, however, question the narrative of a straight road extending from "the Lutheran peasant Enlightenment" (Stråth \& Sørensen 1997) to "the social democratic welfare state", even for Sweden. The story assumes an excess of egalitarian individualism in rural communities of the past and locates too much social democracy in the welfare state. The impact of "the Lutheran peasant

Enlightenment" on the specificities of Nordic welfare-state developments not only stemmed from its power of continuity, but also from its being a target of political criticism. The social policy reforms that shaped the Nordic welfare state were aimed at breaking away from the paternalist structures of personal subordination and control that had been characteristic of rural households and communities and their Lutheran justification, including the humiliating practices of poor relief. Nevertheless, these dynamics and conflicts of Enlightenment thinking seem to have contributed to a strong normative notion of society. Society became conceived of as an actor implementing its own normative standards, as a framework of solidarities and conflicts, and as a target of criticism, knowledge and politics. The interplay between these different "societies" came to be important in the making of the welfare state.

\section{Society as a temporalised concept}

The success stories of Europe's northern periphery have used to highlight the active role played by the nation-state for the integration process with respect to international industrial capitalism (see especially Senghaas 1982), and for good reason. Capitalism in general is a politically constituted mode of economic action, as Karl Polanyi (2001 [1944]) has taught us. This particularly holds true for the Nordic countries. "Capitalism launched by the state" is how Rune Slagstad (1998, 67) describes the aim and achievement of the Norwegian "national strategists" of the nineteenth century. To varying degrees, this characterisation could also be applied to the rest of the Nordic countries, despite the many striking differences in how the nation-building processes played out in northern Europe. As Stein Kuhnle (2011) points out, in the Nordic countries the state had developed significant capacities to produce and utilise information. The state provided (not least, the infrastructural) prerequisites for the expanding market economy, and economic liberalism appeared beneficial to the representatives of the state bureaucracy and those defining the interests of the state. These were the 
two sides of the coin, and an active role for the state in the processes of modernisation gained a remarkable legitimacy, which also became manifest in the use of "society" as a synonym to "state". In the $19^{\text {th }}$ century, the intertwined ideas of historical progress and transnational interdependence became crucial ingredients for the notion of modernising nation-state society. A particular merging of temporal and spatial dimensions was important for the way in which the modernising nation-state society was adopted as the framework for defining social problems and solutions in the countries on Europe's northern periphery. The elite groups that were active in the nation-building processes consciously adopted the distinction between what later was referred to as centre and periphery. ${ }^{3}$ According to this view, the educated elite of a peripheral country, and later popular movements, could and should define their political tasks on the basis of knowledge about the situation in more developed - or more "civilised" - countries. Problems should be anticipated and solutions should be planned by acquiring information on the experiences, solutions and mistakes from countries at the centre of industrial modernisation. ${ }^{4}$ In this pattern of thought a general feature of modern politics, that is, its comparative and historical reflexivity, appeared in a particular way that can be characterised as eclectic peripheral avant-gardism. The outside world provided a framework of external preconditions and constraints, of hopes and threats, of both impulses and alarming ideas, of models and also unpleasant examples, of points of reference and also limits as to what was possible. It was considered important to learn from both the solutions and the mistakes of the more developed countries so as to be able to exploit what Alexander Gerschenkron (1962, 356-363) called "the advantages of backwardness".

"Society" became a temporalised concept in the Koselleckian sense, "an instrument for the direction of historical movement". Two dualisms of modern "society" seem important for its role as such a tool in the making of the Nordic welfare state. Society was conceived of both as an agent and as a target of knowledge and politics, and it was a normative as well as descriptive concept. In texts discussing social problems and their solutions, the concept of society referred to normative criteria and capacities, and these criteria and capacities were then applied to the empirical society in which need, poverty, class divisions, discontent and a lack of discipline were recognised (Kettunen 2000; 2003). These different "societies" appeared, for example, in the Danish debates on old-age pensions in the

\footnotetext{
${ }^{3}$ Marta Petrusewitz (2004) describes similar kinds of peripheral perspectives and intellectual activities by referring to the cases of Poland, Ireland and the Kingdom of the Two Sicilies, 1820-1870.

${ }^{4}$ A good example is a series of articles, which placed "the labour question" on the Finnish political agenda in 1874. It was written by Yrjö Koskinen (Georg Zachris Forsman), one of the foremost leaders of the Finnish nationalist movement. Koskinen (1874) argued that efforts should be made to forestall threats to social stability by examining
} 
late $19^{\text {th }}$ century (Petersen 2010, 333-336). The party manifestos of the Nordic labour parties from the end of the $19^{\text {th }}$ century and the beginning of the $20^{\text {th }}$ century demonstrate all these meanings of "society". They harshly criticised capitalist class society, demanded the fulfilment of the interests of society, and advocated that it was necessary to shift ownership of the means of production to society in general. This would occur only after the working class had achieved power within society.

With respect to the economy, society was a normative representation of the interests of the whole in a dual sense: "society" referred, on the one hand, to the interests of the national economy above any

private economic interests, while on the other hand it referred to the social principle that put limits on economic actions to preserve or reconstruct social cohesion. ${ }^{5}$ These dualisms can be found as characteristics of the modern concept of society, yet in the Nordic countries the notion of "society" assumed a stronger charge of agency and a larger amount of normative power than was the case in many other European countries. An extra normative power was included in Nordic understandings of "society", as this term was and is often used as a synonym for the state or public power. In the 1930s, the relationships between these normative societies and between them and empirical society were reshaped in a way that was crucial for the development of the Nordic welfare states.

The society of virtuous circles

The Nordic political compromises of the 1930s reflected the class structures of the countries and their positions in the international economy, and they drew from the experiences of the Great

Depression and the rise of fascism in Europe. They included political coalitions of "workers and farmers", that is, the Social Democrats and the agrarian parties, and the consolidation of the practice of engaging in collective negotiations and agreements in the industrial labour markets (only the former part applied to Finland before the Second World War). A positive-sum game was supposed to connect the interests of worker-consumers and farmer-producers, on the one hand, and of workers and employers on the other.

\footnotetext{
${ }^{5}$ These two aspects appeared, e.g. in the concepts "societal economy" (samhällsekonomi, samfundsøkonomi, yhteiskuntatalous) and "social policy" (socialpolitik, sosialpolitik, sosiaalipolitiikka/yhteiskuntapolitiikka).
} 
The practical significance of the new employment and economic policies adopted before World War II has been debated. On the level of political discourse, however, the new ideas of a virtuous circle indicated important changes taking place in the 1930s. The virtuous circle included something more than just organised economic interests promoting each other. It was also a virtuous circle between equality, efficiency and solidarity, which, in a sense, can be seen as being based on three different ideological strains of the Nordic modernisation processes: 1) the idealised heritage of the free, independent peasant, 2) the spirit of capitalism and 3) the utopia of socialism. The virtuous circle was supposed to be achieved through compromises between conflicting organised interests and with the support of social planning within national society (Kettunen 2011).

Finnish conditions "from a European perspective", by trying to learn, in other words, from what was happening in countries that were more highly developed than Finland.

A significant part of the Scandinavian class compromises of the 1930s was the reinforced idea of parity between trade unions and employer organisations. Workers and employers should organise symmetrically at various levels of national society, and the organisations were, accordingly, called "labour market parties". They reciprocally recognised the particular and legitimate nature of their interests and committed themselves to taking into account universal interests through their mutual compromises. Trade unions oriented themselves to extending the field of symmetric party relations, that is, to broadening the agenda of collective agreements and, thus, making employers admit the particularism of their interests. The principle of parity was also extended through the corporatist procedures included in economic and social policies. While an interest in controlling the suspected outcomes of the democratic political process was one motive for employers' acceptance of such procedures, trade union representatives saw them as a way of democratising the mode by which "society" upheld its universal interests against particular capitalist interests. Participation in the proper functioning of "society" also made it easier for labour organisations to move from the idea of the working class as the bearer of the universal interest of socialist emancipation to the thought that “society" had been assigned a corresponding historical role (Kettunen 2006).

The beginning, in the 1930s, of what has been characterised as the formative phase of the Nordic welfare states also included a change in the temporalisation of the idea of what it means to be "Nordic". Most notably in Sweden, the previous self-image of living in a poor and peripheral country, and thus the peripheral perspective in relation to the centre, lost much of its previous significance as a way of revealing the code for the future (Andersson \& Hilson 2009). The word "Nordic" became 
loosened from its previous references to nation-states on periphery of modernisation. It was provided with new ideological power, manifested in the emergence in the

1930s of such expressions as "Nordic democracy" and "Nordic society", which referred to a model of a nation-state society that contrasted strongly with notions of backwardness and dictatorship. Much of what had previously been associated with the centre of modernisation was actually now attached to the notion of Nordic society.

A reinforced intra-Nordic centre-periphery mode of thought also appeared, especially, in the relationships between Finland and Sweden. In both countries, the empirical reference point for "the Nordic society" was primarily Sweden. In Finland, Sweden was, from the 1930s, elevated to the level of representing the future path for Finnish society, and this intra-Nordic variant of the centreperiphery distinction was politically influential until the 1980s (Karvonen 1981; Kettunen 2006).

The post-war development in Scandinavia, especially in Sweden, was perceived not only by some Nordic citizens, but also by many outside the Nordic region, as entailing uniquely consistent steps along such a universally applicable road to progress. The trust in a virtuous circle between economic growth, expanding democracy and increased equality was, as such, not specific to the Nordic context. During World War II, it had become a more or less explicit part of the so-called post-war planning in Western countries. At the international level, it was manifested, e.g. in the Philadelphia Declaration of the International Labour Organisation ILO in 1944, a declaration which then served as part of the organisation's constitution (Kettunen 2013). In the Cold War world, more than one candidate for a universally applicable road to progress existed. The notion of a third way, or a middle way when associated specifically with Sweden and sometimes all Norden, included a particular claim of universality, expressed, for example, by maintaining that "freedom and welfare" was the principle of Nordic social political cooperation (Nelson 1953; Salvesen 1956).

\section{The society of immanent critique}

While the notion of change was based on the idea of history as progress, new ingredients were adopted to the view on the dynamics of change. Social change was conceived of as self-reinforcing processes generated by "circular cumulative causation", as Gunnar Myrdal (1957) put it in his theoretical elaboration on this viewpoint. Those processes were often vicious rather than virtuous circles, but the direction could and should be turned by means of knowledge-based societal planning and compromises between all relevant interests. Virtuous circles contained the code for society's future 
change and reform and, thus, the normative standards for assessing the present. This implied an idea of immanent critique: the normative standards of a society served as the criteria by which society could be criticised (Lohmann 1986).

Immanent critique could be applied as a Marxian critique of ideology, with the aim of proving that (bourgeois) society could never meet the normative standards, including freedom and equality, which appeared on its market-faced surface. However, immanent critique could also imply a strong commitment to, or a hegemonic struggle with, what were recognised as the normative standards of society, which then, through a society's political processes, could be applied to the self-criticism of a particular society. In this type of immanent critique, society was criticised in the name of society itself, and this was very much the case in the Nordic countries (Kettunen 1997).

Arguably, the idea of society as an agent with its own normative standards played a particular role in the Nordic countries and implied favourable prerequisites for immanent critique. One contributing factor was a particular type of conformity based on the Lutheran tradition that was secularised in the various Nordic nationalisms (Stenius 1997). Conformity by no means implied an absence of class conflicts and class consciousness. Rather, the construction of the nation as an “imagined community" (Anderson 1983) offered a normative code against which socially subordinated groups could contrast their individual and local experiences of suppression and injustice, and generalise from these experiences to form a political class consciousness. The idea of a society being able to anticipate, criticise and revise itself was then, in the 1930s, promoted by the class compromises between workers, farmers and the bourgeoisie, and by the agenda-setting power of reformist socialism.

The normative standards of society were not only moral rules, but also rules for the most rational functioning and rationalisation of society. They were also rules for how the productive capacities of individuals could be released as well as rules concerning the contents of those capacities, such as selfdisciplined citizenship. In the ideational framework of a modernising nation-state society, the perspectives of economic rationalisation and social integration intersected.

In the late $19^{\text {th }}$ century the concept of society came to refer to economic activities (samfunds $\phi$ konomi, samhällsekonomi, yhteiskuntatalous) at the national level at the same that it also came to refer to the social principle putting limits on economic activities for preserving or restoring social order and cohesion (socialpolitik, sosialpolitik, yhteiskuntapolitiikka/sosiaalipolitiikka). In the early $20^{\text {th }}$ century, the national economy and social policy grew more distinct as fields of knowledge and policy; 
yet they had become, since the 1930s, interlinked as different parts in what were conceived of as welfare-generating virtuous circles.

As an attribute of economic life, the adjective "societal", which directly derived from the word for "society" - in Swedish samhällelig, in Norwegian and Danish samfundsmessig, in Finnish yhteiskunnallinen - was associated with the principles of a "planned economy", which during the economic depression of the 1930s became, internationally, a popular objective, one with various political colours. Accordingly, "society" would actively steer and rationalise the economy. The formulators of the Norwegian Labour Party programme, for example, raised demands for a "societal economic initiative" (samfundsmessig фkonomisk initiativ) and a "societally planned economy" (den samfundsmessige planфkonomi) (Slagstad 1998, 192).

In the context of economic rationalisation, the word "social" (social, sosial, sosiaalinen) had a quite different meaning. It was associated with delimiting or compensating for those particular outcomes of capitalist economic rationalisation that endangered the welfare of those involved (notably the workers) and threatened the cohesion of society. The strong links between the concepts of state and society contributed to the masculine connotations of "societal", which carried over into public power and the domain of public life. As for "social", its meaning was limited to what was between society and the family, or between the public and private domains, and was thereby demarcated as feminine. The distinction between "societal" and "social" also offered tools for conceptualising the notion of a society of virtuous circles. Pekka Kuusi, a Finnish scholar and practitioner of social policy, published in 1961 a book that is often regarded as laying out the plan for the Finnish welfare state. Kuusi did not use the concept of welfare state, but elaborated a hierarchy between societal policy (yhteiskuntapolitiikka) and social policy (sosiaalipolitiikka). The latter was part of the former, and those persons shaping social policy had to clarify for themselves the goals of general societal policy. Inspired by Gunnar Myrdal's theory of circular cumulative causation, Kuusi expressed his strong confidence in the possibilities of turning vicious circles into virtuous ones within modern society: "Democracy, social equalization and economic growth seem to be fortunately interrelated in modern society. Social policy seems to spring from free and growth-oriented human nature" (Kuusi 1961, 8; 1964, 34). In the "growth-oriented society", "social" was no longer a counterprinciple to "economic"; with the support of a comprehensive long-term "societal policy", social, economic and political factors would work interdependently in the self-reinforcing process of progress. The society, "our society", was simultaneously the subject, object and framework of such growth-oriented action. 


\section{Unsustainable society?}

It has been argued in debates on postmodernity and globalisation that the modern Western concept of society is too strong and too limited to sustain. It is too strong when referring to "an integrated holistic entity" (Featherstone 1995, 134), with progress and rationalisation as its inherent dynamics, and too limited due to its ties with the nation-state and national borders. Obviously, "society" in Nordic political discourses bears those characteristics that have been referred to as being part of the unsustainable modern idea of society.

However, even in the time of EU citizenship, globalised financial markets and increased crossborder mobility, defining "society" in a way that extends beyond the borders of the nation-state is more probably a conscious provocation than an indicator of a gradually eroding concept. The expression "European society" is mostly used in the same way as it was in the $19^{\text {th }}$ century: a national society in Europe, for example Norway or Finland. We do not find much talk about Europe as a society (Delanty 2016; Kettunen 2018).

The discussion of different "models" has barely questioned the ways in which the concept of society is tied to the nation-state. It reflected an end of inter-systemic rivalry between socialism and capitalism in their existing or envisioned forms and the globalisation of capitalism. This implied a new comparative interest in the varieties of (welfare) capitalism, yet in a way that took the nationstates, and national societies, as self-evident units in attempts to distinguish between different "welfare regimes" among different groups of countries, or "worlds of welfare capitalism" (EspingAndersen 1990). The notion of a model, for example "the Nordic model", has referred either to institutional continuities challenged by globalisation or to the best practices of responding to challenges, transferred via transnational policy learning processes; but in both cases, "comparative imagination" (Fredrickson 2000; Sluga 2004) is focused on the differences and similarities between national societies.

The critique of the welfare state in the 1980s and 1990s did question the conventional Nordic uses of the term "society". Did not this critique, notably the aforementioned attempts to get rid of the confusion between "state" and "society", manage to change the references, contexts and valuations of the concept of society?

While the popularity of the welfare state concept greatly increased only after the end of welfarestate expansion in Western Europe, the concept of society took on a new kind of use in critiques of the 
welfare state. Since the late 1970s, in connection with the diagnoses of "the crisis of the welfare state" and based on the advice of the OECD, "welfare society" was adopted as a tool of critique for what was seen as an overly large public sector and a bureaucratic and patronising welfare state (Leimgruber 2013, 293-309). The conceptual distinction between state and society was linked with the international emergence of "civil society" in the 1980s as a concept used to refer to the sphere of private and voluntary actors and activities.

However, in the Nordic countries any attempt to create a political alternative by contrasting the concepts of state and society faced heavy constraints imposed by linguistic conventions. Conflating these two concepts, notably using "society" as a term for the state and public sector, did not simply result from the expansion of welfare-state interventions and corporatist institutions. The understanding of the state as a society was based on earlier layers of state formation, and it had created the preconditions for the making of the welfare state by legitimating state interventions and the representation of collective interests.

"Welfare society" proved to be an ineffective tool for critiquing the Nordic welfare states. As such, it was by no means novel in the 1980s. "Welfare society" had been used interchangeably with "welfare state" or else analogically with such expressions as "industrial society", that is, as a description of prevailing socio-economic circumstances and developments. In the 1980s and 1990s, "welfare state" was often consciously replaced by "welfare society" in national discourses, but the risk of counterproductive consequences was obvious. "Welfare society" could turn into support for the legitimacy of the welfare state, because in the long Nordic tradition "society" represents the general and public against the particular and private.

In any case, also "welfare state" currently enjoys great popularity in the Nordic countries. Those concerned about economic competitiveness or who advocate for budgetary discipline and austerity politics motivate these concerns via the necessity to create or rescue resources for the welfare state. The welfare state may appear as an argument for restrictive immigration policies or for the promotion of labour immigration. Those defending the welfare state against the pressures of globalised capitalism argue that the welfare state, via its security networks and risk-sharing systems, actually generates competitive advantages. Rescuing the welfare state seems to be a goal that sanctifies the means and a means that sanctifies the goal.

Since former issues on the political agendas of various national societies are perceived of as external, imperative conditions of the global market, the notion of the national "imagined community" is being reproduced, even reinforced. However, this is occurring in a way that tends to push aside some of 
those ingredients most important to the concept of society in its Nordic usages during the making of the welfare state. In a competitive community, social problems tend to be defined as issues of individual behaviour, and policies are aimed to create incentives for better behaviour. This does not exclude the protection of the weak, but weakness is associated with individual properties rather than structural asymmetres of social relations. We may find here the notion of a warm community in contrast to that of a cool society, which has historically been associated with the Nordic-type welfare states. The change is, however, not just paradoxical but also controversial. While the emphasis on "us" in the making of competitive territorial (most notably national) communities is an integral part of globalised economic competition, the same transformations may also erode the solidarity based on common spatial ties. They may also open up new cross-national and cross-territorial perspectives for defining "us".

\section{References}

Anderson, Benedict (1983) Imagined Communities. Reflections on the Origin and Spread of Nationalism. London and New York: Verso.

Andersson, Jenny (2006) Between Growth and Security. Swedish Social Democracy from a Strong Society to a Third Way. Manchester: Manchester University Press.

Andersson, Jenny \& Hilson, Mary (2009) "Images of Sweden and the Nordic Countries", Scandinavian Journal of History, 34(3), 219-228.

Aronsson, Peter (1995) “The possibilities of conceptual history 'from above' and 'from below': Reflections on samhälle 'society' in Sweden, 1700 to 1990", in Carlos Barros (ed.), Historia a Debate, tomo II, Retorno del Sujeto, Actas del Congreso Internacional "A historia a debate" celebrade el 711 de julio de 1993 en Santigao de Compostela, pp. 237-260.

Aronsson, Peter (1997) "Local Politics -The Invisible Political Culture”, in Øystein Sørensen and Bo Stråth (eds.), The Cultural Construction of Norden, Oslo: Scandinavian University Press, pp. 172205.

Béland, Daniel \& Petersen, Klaus eds. (2014) Analysing Social Policy Concepts and Language: Comparative and Transnational Perspectives. Bristol: Policy Press,

Berggren, Henrik \& Trägårdh, Lars (2006) Är svensken människa? Gemenskap och oberoende $i$ der moderna Sverige, Stockholm: Norstedts.

Bobbio, Norberto (1989) Democracy and Dictatorship. The Nature and Limits of State Power. Translated by Peter Kennealy. Cambridge: Polity Press.

Bowers, John \& Iwi, Kate (1993) “The discursive construction of society”, Discourse \& Society, 357393. 
Delanty, Gerard (2016), “The making of European society: contesting methodological nationalism', Innovation", The European Journal of Social Science Research, 29, 3-15.

Edling, Nils (2006) "Limited Universalism: Unemployment insurance in Northern Europe 19002000", in N. F. Christiansen, K. Petersen, N. Edling \& P. Haave (eds.), The Nordic Model of Welfare - a Historical Reappraisal. Copenhagen: Museum Tusculanum Press, pp. 99-143.

Edling, Nils (2013) "The primacy of welfare politics. Notes on the language of the Swedish Social Democrats and their adversaries in the 1930s", in Heidi Haggrén, Johanna Rainio-Niemi \& Jussi Vauhkonen (eds.), Multilayered-Historicity of the Present. Approaches to social science history. Helsinki: University of Helsinki, pp. 125-150.

Edling, Nils ed. (2019) The Changing Meanings of the Welfare State: The History of Political Key Concept in the Nordic Countries. Oxford: Berghahn.

Enjolras, Bernard \& Strømsnes, Kristin eds. (2018) Scandinavian Civil Society and Social Transformation: The Case of Norway. Cham: Springer.

Esping-Andersen, Gosta (1990) The Three Worlds of Welfare Capitalism. Cambridge: Polity Press.

Featherstone, Mike (1995) Undoing Culture. Globalization, Postmodernism and Identity. London: Sage Publications.

Fredrickson, George M. (2000) The Comparative Imagination. On the History of Racism, Nationalism, and Social Movements. Berkeley: University of California Press.

Gerschenkron, Alexander (1962) Economic Backwardness in Historical Perspective. A Book of Essays. Cambridge, Mass.: The Belknap Press of Harvard University Press.

Götz, Norbert (2001) Ungleiche Geschwister: Die Konstruktion von nationalsozialistischer Volksgemeinschaft und schwedischem Volksheim. Die kulturelle Konstruktion von Gemeinschaften.

4. Diss. Baden-Baden: Nomos.

Heilbron, Johan (1995) The Rise of Social Theory. Cambridge: Polity Press.

Karvonen, Lauri (1981) "Med vårt västra grannland som förebild”: en undersökning av policydiffusion från Sverige till Finland. Åbo: Stiftelsens för Åbo akademi forskningsinstitut.

Kettunen, Pauli (1997) “The Society of Virtuous Circles”, in Pauli Kettunen \& Hanna Eskola (eds.), Models, Modernity and the Myrdals. Renvall Institute Publications 8. Helsinki: The Renvall Institute for Area and Cultural Studies, University of Helsinki, pp. 153-173.

Kettunen, Pauli (2000) “Yhteiskunta - 'Society' in Finnish", Finnish Yearbook of Political Thought 2000, Vol 4. Jyväskylä: SoPhi, 159-197.

Kettunen, Pauli (2003) "Yhteiskunta", in Matti Hyvärinen, Jussi Kurunmäki, Kari Palonen, Tuija Pulkkinen \& Henrik Stenius (eds.), Käsitteet liikkeessä. Suomen poliittisen kulttuurin käsitehistoria. Vastapaino, Tampere 2003, 167-212.

Kettunen, Pauli (2006) "Power of International Comparison - A Perspective on the Making and Challenging of the Nordic Welfare State", in Niels Finn Christiansen, Klaus Petersen, Nils Edling and Per Haave (eds.), The Nordic Model of Welfare - a Historical Reappraisal. Copenhagen: Museum Tusculanum Press, 31-65.

Kettunen, Pauli (2011) "The Transnational Construction of National Challenges: The Ambiguous Nordic Model of Welfare and Competitiveness", in Pauli Kettunen \& Klaus Petersen (eds.), Beyond Welfare State Models. Transnational Historical Perspectives on Social Policy. Cheltenham: Edward Elgar, 16-40. 
Kettunen, Pauli (2013) “The ILO as a Forum for Developing and Demonstrating a Nordic Model”, in Sandrine Kott \& Joelle Droux (eds.), Globalizing social rights. The International Labour Organization and Beyond. Basingstoke and New York: Palgrave Macmillan, 210-230.

Kettunen, Pauli (2014) "The Language of Social Politics in Finland", in Daniel Béland \& Klaus Petersen (eds.), Analysing Social Policy Concepts and Language: Comparative and Transnational Perspectives. Bristol: Policy Press, 157-176.

Kettunen, Pauli (2018) "The concept of nationalism in discussions on a European society". Journal of Political Ideologies, Vol 83, Issue 3.

Kildal, Nanna \& Kuhnle, Stein eds. (2005) Normative Foundations of the Welfare State - The Nordic Experience. London/New York: Routledge.

Knudsen, Tim \& Rothstein, Bo (1994) "State Building in Scandinavia”, Comparative Politics 1, 203 220.

Koselleck, Reinhart (1979) Vergangene Zukunft. Zur Semantik geschichtlicher Zeiten. Frankfurt am Main: Suhrkamp.

Koskinen, Yrjö (1874), “Työväen-seikka I-III”, Kirjallinen Kuukauslehti, 1, 4, 8.

Kuhnle, Stein (2011) "International Modeling in the Making of the Nordic Social Security Systems", in Pauli Kettunen \& Klaus Petersen (eds.), Beyond Welfare State Models. Transnational Historical Perspectives on Social Policy. Cheltenham: Edward Elgar, 65-81.

Kurunmäki, Jussi \& Strang. Johan (eds.) (2011) Rhetorics of Nordic Democracy. Studia Fennica Historica 17. Helsinki: Finnish Literature Society.

Kuusi, Pekka (1961) 60-luvun sosiaalipolitiikka. Porvoo: WSOY.'

Kuusi, Pekka (1964) Social Policy for the Sixties: A Plan for Finland. Helsinki: Finnish Social Political Association.

Larsson, Jan (1994) Hemmet vi ärvde. Om folkhemmet, identiteten och den gemensamma framtiden. Stockholm: Arena.

Leimgruber, Matthieu (2013) "The Embattled Standard-bearer of Social Insurance and its Challenger: the ILO, the OECD, and the Crisis of the Welfare State (1975-1985)", in Sandrine Kott \& Joelle Droux (eds.), Globalizing social rights. The International Labour Organization and Beyond (Basingstoke and New York: Palgrave Macmillan), 293-309.

Lohmann, Georg (1986) "Marx's Capital and the Question of Normative Standards", Praxis International, 6(3), 353-372.

Myrdal, Gunnar (1957) Economic Theory and Underdeveloped Regions. London: Duckworth.

Nelson, George R. ed. (1953) Freedom and Welfare: Social Patterns in the Northern Countries of Europe, Copenhagen: The Ministries of Social Affairs of Denmark, Finland, Iceland, Norway, Sweden.

Petersen, Jørn-Henrik (2010) "Debatten om alderdomsforsørgelse frem mod alderdomsforsørgelsesloven af 1891. Baggrund og indhold", in Jörn henrik Petersen, Klaus Petersen \& Niels Finn Christiansen (eds.), Frem mod socialhjaelpsstaten. Dansk Velfaerdshistorie, bind 1, 1536-1898. Odense: Syddansk Universitetsforlag, 311-390.

Petersen, Klaus (2006) "Constructing Nordic Welfare? Nordic Social Political Cooperation 19191955", in Niels Finn Christiansen, Klaus Petersen, Nils Edling and Per Haave (eds.), The Nordic Model of Welfare - a Historical Reappraisal. Copenhagen: Museum Tusculanum Press, 67-88. 
Petersen, Klaus \& Åmark, Klas (2006) “Old Age Pensions in the Nordic Countries, 1880-2000”, in N. F. Christiansen, K. Petersen, N. Edling \& P. Haave (eds.), The Nordic Model of Welfare $-a$ Historical Reappraisal. Copenhagen: Museum Tusculanum Press, 145-188.

Petrusewicz, Marta (2004) "The Modernisation of the European Periphery; Ireland, Poland, and the Two Sicilies, 1820-1870: Parallell and Connected, Distinct and Comparable", in Deborah Cohen and Maura O'Connor (eds.), Comparison and History, Europe in Cross-national Perspective. New York and London: Routledge, 145-65.

Polanyi, Karl (2001 [1944]) The Great Transformation. The Political and Economic Origins of Our Time. Foreword by Joseph E. Stiglitz. Boston: Beacon Press.

Riedel, Manfred (1975) "Gesellschaft, bürgerliche", Geschichtliche Grundbegriffe. Historisches Lexikon zur politisch-sozialen Sprache in Deutschland. Herausgegeben von Otto Brunner, Werner Conze, Reinhart Koselleck. Band 2. E-G. Stuttgart: Ernst Klett Verlag.

Rose, Nikolas (1999) Powers of Freedom. Reframing Political Thought. Cambridge: Cambridge University Press.

Salvesen, Kaare (1956) "Co-operation in Social Affairs between the Northern Countries of Europe", International Labour Review, LXXIII, 334-57.

Senghaas, Dieter (1985) The European Experience. A Historical Critique of Development Theory.

Leamington Spa: Berg.

Slagstad, Rune (1998) De nasjonale strateger. Oslo: Pax Forlag A/S.

Sluga, Glenda (2004) "The Nation and the Comparative Imagination", in Deborah Cohen \& Maura O'Connor (eds.), Comparison and History. Europe in Cross-national Perspective. New York and London: Routledge, pp. 103-114.

Stenius, Henrik (1997) "The Good Life is a Life of Conformity: The Impact of Lutheran Tradition on Nordic Political Culture", in Øystein Sørensen \& Bo Stråth (eds.), The Cultural Construction of Norden. Oslo: Scandinavian University Press, pp. 161-171.

Stråth, Bo \& Sørensen, Øystein (1997) "Introduction”, in Øystein Sørensen \& Bo Stråth (eds.), The Cultural Construction of Norden. Oslo: Scandinavian University Press, 1-24.

Touraine, Alain (1995) Critique of Modernity. London: Blackwell.

Trägårdh, Lars ed. (1995) Civilt samhälle kontra offentlig sector. Stockholm: SNS Förlag.

Trägårdh, Lars (1997) "Statist Individualism: On the Culturality of the Nordic Welfare State", in Øystein Sørensen \& Bo Stråth (eds.), The Cultural Construction of Norden. Oslo: Scandinavian University Press, 253-285.

World Economic Forum (2011) Shared Norms for the New Reality: The Nordic Way. Stockholm: Global utmaning. 